\title{
THE VISUAL PROCESSING OF MOTION
}

A meeting organized by the CNRS (Life Science Department) in the framework of the "Conferences Jacques Monod"

The meeting will take place in Roscoff (Brittany, France) from June 19 to June 23, 1989. Applicants should contact:

\section{Dr. N. Franceschini, Chairman \\ Laboratoire de Neurobiologie \\ 31 Chemin Joseph Aiguier \\ 13402 MARSEILLES \\ CEDEX 9, FRANCE}

Telephone: $91-22-41-29$

EARN: FRCHINI at FRMOP11

\section{SPEAKERS INCLUDE:}

C. Bonnet

O. Braddick

E. Buchner

P. Buisseret

J. Bullier

V. Conilleau-Perez

J. Cremieux

M. Egelhaaf

R. Emerson

O. Faugeras

N. Franceschini

Y. Fregnac

K. Götz

P. Hammond

H. van Hateren

K. Kausen
M. Imber

A. Kaneko

K. Kirschfeld

C. Koch

S. Laughlin

R. Masland

D. Mestre

W. Newsome

G. Orban

C. Oyster

J. M. Pichon

W. Reichardt

F. Schuling

M. Srinivasan

V. Torre

R. DeVoe 
Please enter my subscription to VISUAL NEUROSCIENCE

(ISSN 0952-5238)

Vols. 2 and 3, 1989, monthly

Two volumes of six issues each.

\section{口 $\$ 280.00$ Institutions \\ 口 \$120.00 Individuals* \\ 口\$80.00 Students*}

*Discounted individual and student rates payable by personal check or credit card only. Students must supply proof of current enrollment.

Please note: If paying by credit card, enclose this card in an envelope for your security.

\section{Name of subscriber}

Address

City State/Prov.

Payment enclosed. (Payment may be made in U.S. dollars or equivalent in Canadian dollars.)

\begin{tabular}{l}
$\square$ VISA \\
Card no. $\square$ MasterCard (Interbank no. \\
\hline Signature
\end{tabular}

No postage necessary if mailed in the U.S.

Cambridge University Press, 32 East 57th Street. New York, NY 10022

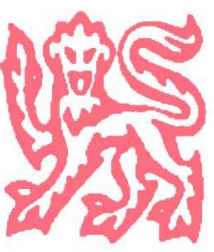

Please enter my subscription to VISUAL NEUROSCIENCE (ISSN 0952-5238)

Vols. 2 and 3, 1989, monthly

Two volumes of six issues each.

口 $\$ 280.00$ Institutions

$\$ 120.00$ Individuals*

口 $\$ 80.00$ Students*

*Discounted individual and student rates payable by personal check or credit card only. Students must supply proof of current enrollment.

Please note: If paying by credit card, enclose this card in an envelope for your security.

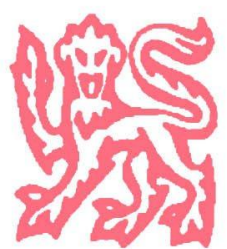

Please enter my subscription to VISUAL NEUROSCIENCE (ISSN 0952-5238)

Vols. 2 and 3, 1989, monthly

Two volumes of six issues each.

\section{£182.00 Institutions \\ £84.00 Individuals* \\ E58.00 Students*}

- Discounted individual and student rates payable by personal check or credit card only. Students must supply proof of current enrollment.

Please note: If paying by credit cand, enclose this card in an envelope for your security.

\begin{tabular}{lll}
\hline Name of subscriber & \\
\hline Address & State/Prov. & Zip
\end{tabular}

$\square$ Payment enclosed. (Payment may be made in U.S. dollars or equivalent in Canadian dollars.)
$\square$ VISA $\square$ MasterCard (Interbank no.
Card no. Expires

Signature

No postage necessary if mailed in the U.S.

Cambridge University Press, 32 East 57th Street, New York, NY 10022

Please send this form to any bookseller or subscription agent or direct to Cambridge University Press, The Edinburgh Building, Shaftesbury Road, Cambridge CB2 2RU, England.

Orders sent to the Press must be accompanied by payment which may be made, in sterling by cheque, UK Postal Order International Money Order, bank transfer sterling, by cheque, ${ }^{\prime}$ UK Postal Order, International Money Order, bank transter (Barclay's Bank Ltd, 15 Bene't St., Cambridge CB2 3PZ; a/c no. 70205931 , Bank Code no. 20-17-19) or by Post Office Giro (a/c no. 571 6055 GB). Payment may also be made by Barclaycard/ViSABBankAmericard of Access/MasterCard/Eurocard. If payment is order to the Press. Cheques should be made payable to Cambridge University Press.

$\square$ Payment enclosed

$\square$ Payment by Barclaycard/VISA or Access/MasterCard/

Eurocard

Signature of cardholder

Date Amount

Barclaycard/VISABankAmericard number

Access/MasterCard/Eurocard number

Name of subscriber 


$\underset{\text { FIRST CLASS }}{\text { BUSINESS }} \underset{\text { PERMIT NO. } 5206}{\text { REPLY }} \underset{\text { NEW YORK, NY }}{\text { MAIL }}$

POSTAGE WILL BE PAID BY ADDRESSEE

\section{CAMBRIDGE UNIVERSITY PRESS}

Attn: Journals Department

32 East 57 th Street

New York, N.Y. 10022
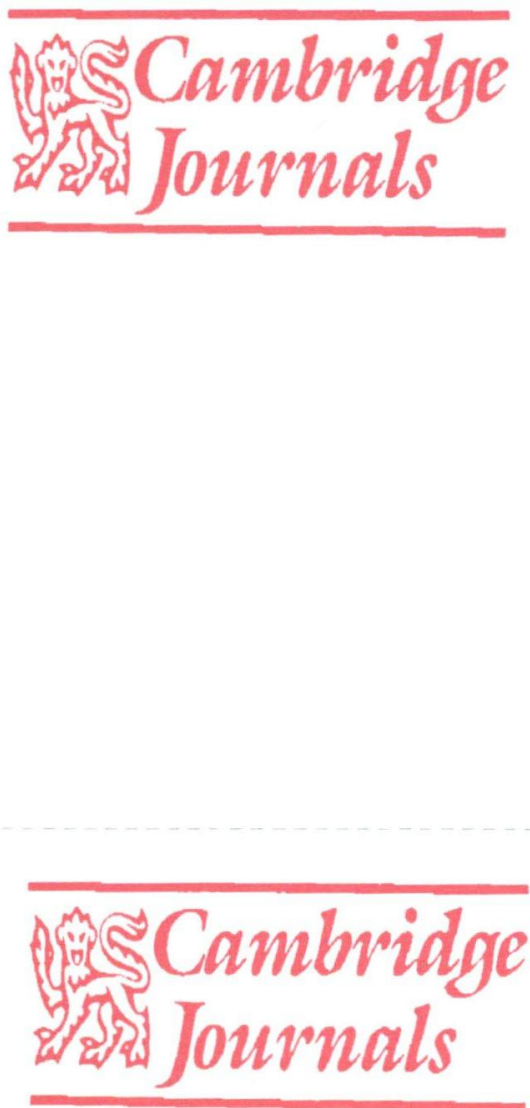

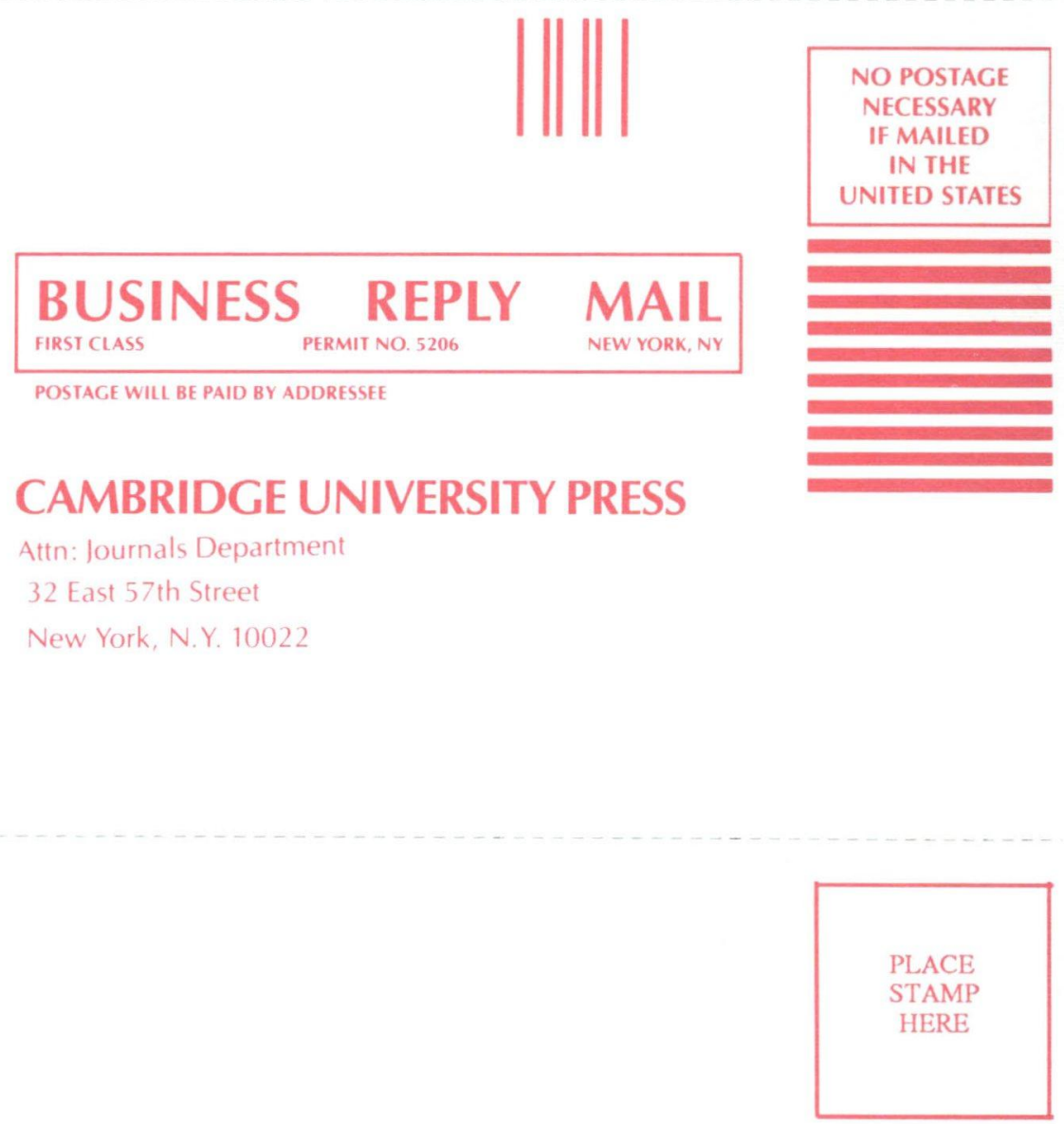

CAMBRIDGE UNIVERSITY PRESS

The Edinburgh Building

Shaftesbury Road

Cambridge CB2 2RU

England 


\section{THE JOURNAL OF PHYSIOLOGY}

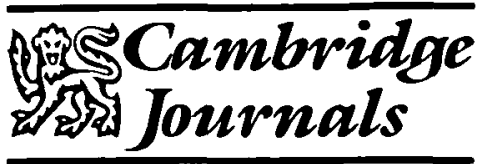

Published for the Physiological Society

\section{Chairman of the Editorial Board:}

\section{A. V. Edwards, University of Cambridge}

This internationally respected journal publishes high quality papers representing original experimental work in three areas: general physiology, mammalian physiology, and human physiology. Each hardbound monthly volume of The Journal of Physiology is concerned with respiration, circulation, excretion, reproduction, digestion, homeostasis, and particularly neurophysiology and muscular contraction. Abstracts of scientific meetings of the Physiological Society, which are accepted by the members present at those meetings, are also published. A Cumulative Subject and Author Index is produced triennially and an Annual Index is produced in the intervening years.

\section{THE JOURNAL OF} PHYSIOLOGY m.r......

TIIE PIIYSIOLOGICAL SOCHITY $\because \ldots$

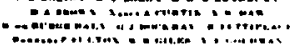
- A

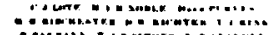

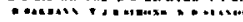
A a

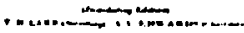

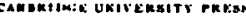

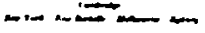

Selected papers

Co-ordinated variations in chloride-dependent potassium transport and cell water in normal human erythrocytes, G. W. Stewart

Influence of right atrial stretch and atrial natriuretic factor on rate intestinal fluid content, $S$. Kaufman \& $E$. Monckton

Outward rectification of inhibitory postsynaptic currents in cultured rat hippocampal neurons, J. L. Barker \& $N$. L. Harrison

Review Lecture: Capillary permeability and how it may change, C. C. Michel

The Journal of Physiology (ISSN 0022-3751) is published monthly in 1989 . Subscription to volumes 408419: $\$ 1200.00$ per year; $\$ 106.00$ per volume.

Back Volumes: $254-407$ (1976-1988) $\$ 115.00$ each.

Journals Department

Cambridge University Press

32 Eist 57th Sireet, New York, NY 10022 USA; or

The Fdinburgh Building, Cambridge CB2 2RU, UK 


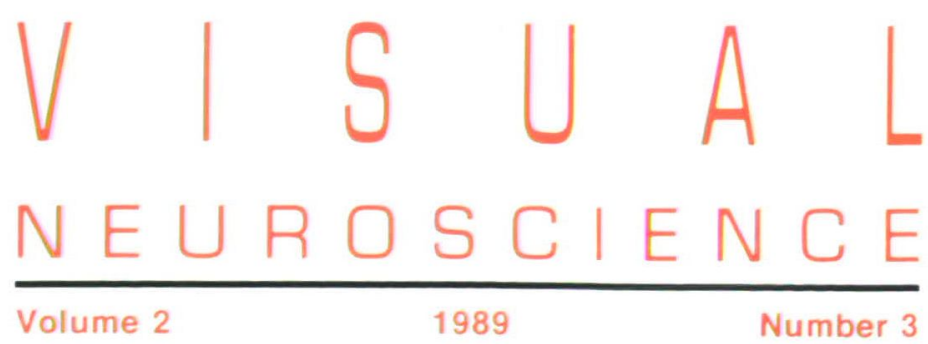

STEPHEN R. ROBINSON, Bogdan DREHER, AND Murray J. McCall

L.C.L. SILVEIRA, C.W. Picanço-Diniz, and E. Oswaldo-Cruz

JinTana SatTayasai, JoE ZAPPIA, AND DAvid EHRLICH

Craig W. Hawryshyn, Margaret G. ARNOLD Duane J. Chaisson, and Patricia C. Martin

T. FitzGibBon AND W. BURKe

R.J. Clarke, R.A. Giolli, R.H.I. Blanks, Y. ToRigoe, AND J.H. FALLON

BARBARA G. Korp, Robert H.I. BLANKS, AND Yasuhiro TORIgoE

Michael Conley and David FitzPatrick

JONATHAN D. VICTOR and Mary M. Conte

Margarete Tigges, JOHANNES TIGgES, JOHN K. MCDONALD, Michael Slattery, and AlCides Fernandes

\section{CONTENTS}

201 Nonuniform retinal expansion during the formation of the rabbit's visual streak: Implications for the ontogeny of mammalian retinal topography

221 Distribution and size of ganglion cells in the retinae of large Amazon rodents

237 Differential effects of excitatory amino acids on photoreceptors of the chick retina: An electron-microscopical study using the zinc-iodide-osmium technique

247 The ontogeny of ultraviolet photosensitivity in rainbow trout (Salmo gairdneri)

255 Representation of the temporal raphe within the optic tract of the cat

269 Neurons of the medial terminal accessory optic nucleus of the rat are poorly collateralized

275 Projections of the nucleus of the optic tract to the nucleus reticularis tegmenti pontis and prepositus hypoglossi nucleus in the pigmented rat as demonstrated by anterograde and retrograde transport methods

287 Morphology of retinogeniculate axons in the macaque

297 Cortical interactions in texture processing: Scale and dynamics

315 Postnatal development of neuropeptide Y-like immunoreactivity in area 17 of normal and visually deprived rhesus monkeys

329 Detailed Information for Contributors

330 The Humane Care and Use of Animals 